\title{
The application of grey water recycling at Gayanti City Apartment, South Jakarta
}

\author{
$A$ Muthiya $^{1}, T$ Tazkiaturrizki ${ }^{2}$, and $R$ Ratnaningsih ${ }^{1}$ \\ ${ }^{1}$ Trisakti University, Environmental Engineering Department, Faculty of Landscape Architecture and Environmental Technology, Jl. \\ Kyai Tapa No. 1, Jakarta Barat 11440, Indonesia
}

\begin{abstract}
This planning is aim to design the plumbing system at Gayanti City Apartment with a separate system or grey water recycling system so that the efficiency cost of the recycling system will be known. Clean water system from PAM JAYA DKI and recycle water system from grey water that distributed to Waste Water Treatment Plant (WWTP) to be treated and reused for flushing closet and watering plants are designed for this apartment. The amount of the clean water needed is $116.6 \mathrm{~m}^{3} /$ day and the amount of the recycle water needed is $18.64 \mathrm{~m}^{3} /$ day. Water supply system that applied to this apartment is roof tank system. Calculation of water consumption's fluctuations to determine the capacity of reservoirs and pumps are using Four Winds Apartment, Bellagio Apartment, Thamrin Residences Apartment, and Karet Kuningan Apartment as a comparison with the same criteria as the designed apartment. The capacity of the clean ground water tank is $123.5 \mathrm{~m}^{3}$ and the recycle ground water tank is $12 \mathrm{~m}^{3}$. Transfer pumps work for 12 hour/day (1 time pause) and the capacity of clean roof water tank is $31.5 \mathrm{~m}^{3}$ and the recycled one is $6.7 \mathrm{~m}^{3}$. Based on the chosen alternative in design, Gayanti City Apartment is using the first water supply system alternative that needs 18 stand pipes of clean water and 18 stands pipes of recycle water with 4 PRVs mounted on each stand pipes and booster pump installed for the top 6 floors. The amount of clean water needed is $116.6 \mathrm{~m}^{3} /$ day and recycle water is $18.64 \mathrm{~m}^{3} /$ day. Waste water produced is equal to $93.28 \mathrm{~m}^{3}$ which $80 \%$ of it is the grey water that will be treated in Waste Water Treatment Plant into recycle water. Total amount of clean and recycled water investment and reservoir constructions is Rp. 1,637,227,201,- and percentage of clean water that can be saved from the application of recycling system is $18 \%$ with total efficiency cost Rp 233,932/day or Rp 7,017,960/month.
\end{abstract}

\section{Introduction}

The availability of water within a city will be affected by population growth. With the increase in the number of population so then the amount of water demand will increase and if it's not managed properly will cause water scarcity. One solution to deal with water scarcity is by doing water conservation. Water conservation is an effort to efficient the use of water so the waste of water can be avoided [1].

Increasing population also led to an increase in the needs of residents so that the apartment was built. Apartments are considered as a practical residence because it is located in downtown and makes people easy to perform activities. In addition, the apartment also saves the land for manufacturing residents as long as it is an environmentally friendly apartment which called green building.

Green buildings are buildings that environmentally and resources responsible to efficient from the time of planning, construction, utilization, maintenance, and deconstruction [1]. The Regulation on Green Building [1], encourages the management of buildings water saving. One aspect of green building implementation is water conservation which minimizing clean water consumption and maximizing the use of recycled water for watering plants, flushing toilets, and urinals [2].

Gayanti City Apartment is one of the loft or mezzanine building concept which located in Gatot Subroto area, South Jakarta and built on an area of 1.45 ha and building area of $14.82 \mathrm{Ha}$. In this apartment, plumbing system will be planned which refers to SNI 8153-2015 with grey water recycling system for flushing toilet and urinal as well as watering plants.

This planning is aim to design the plumbing system at Gayanti City Apartment with a separate system or grey water recycling system so that the efficiency cost of the recycling system will be known.

\section{Methods}

Gayanti City Apartment is located on Jl. Gatot Subroto Kav.2 in West Kuningan, Mampang Prapatan, South Jakarta. This apartment has 2 residential towers which are tower $\mathrm{A}$ and tower $\mathrm{B}$ and 1 office tower. The first construction stage of this apartment is tower A. Tower A consists of 32 floors with 8 types of residential units

\footnotetext{
* Corresponding author: ratnaningsih $@$ trisakti.ac.id
} 
from $3^{\text {rd }}$ to the $32^{\text {nd }}$ floor. The supporting facilities for guests and occupants, such as parking area, clinics, optics, and public toilets are located on the $4^{\text {th }}$ basement floor to the $2^{\text {nd }}$ floor. The types of residential units in this apartment are 3 Bedroom-Maid, 2 Bedroom-Maid, 1 Loft Bedroom type A-B-C-D, 1 Bedroom-A, and 1 Bedroom-B.

Stages of planning at Gayanti City Apartment consists of determine the location and planning time. Then, primary and secondary data collection wherein as the primary data is fluctuations measurement in water consumption from the comparative Apartments taken Thamrin Residences Apartment, and Karet Kuningan Apartment will be used as a reference to design the reservoir capacity and as secondary data is the floor plan and land area from the masterplan. Reference, guidelines, and literature used are theories related to plumbing system based on books, journals, SNI, and Governor Regulations. Data analysis consists of planning clean water and recycled water systems. To determine the amount of clean and recycled water needed is obtained by the following formula [3]:

$$
\mathrm{Q}_{\text {day }}=\sum \text { Population (personx Water demand }
$$

The population and water needs of the comparative apartment used to determine the water demand of designed apartment. Wastewater generated ranges from $80 \%-90 \%$ of clean water [4]. The grey water produced from residential can reach $80 \%$ of waste water so that the black water is equal to $20 \%$ of the waste water [5]. The dimensions of the stand pipes and the critical point of the building can be determined through the Gayanti City Apartment masterplan by creating clean water and recycled water distribution line from the floor plan. The capacity of transfer and booster pumps is determined through the needs of clean water and recycling water of Gayanti City Apartment. From the data analysis, investment cost of clean water and recycled water pipes, accessories, and pump, reservoir construction cost, and efficiency cost will be obtained. from Four Winds Apartment, Bellagio Apartment,

\section{Results and discussion}

\subsection{Clean and recycled water supply systems}

Gayanti City Apartment has two water supply systems those are clean water and recycled water system using PPR PN-10 pipe. Recycled water is used for flushing closets and watering plants. The source of clean water used in Gayanti City Apartment is from PAM JAYA DKI Jakarta, while the recycled water comes from sink, floor drain, washing machine, bath tub, and kitchen sink that has been treated at the Waste Water Treatment Plant (WWTP).

Both water supply systems implement a roof tank system. Clean water from PAM JAYA, supplied continuously for 24 hours, is collected firstly in Ground Water Tank (GWT) located in basement 1. Then the water that has been collected in GWT is transferred using a transfer pump to the roof tank (RT) located on the roof floor. Furthermore, water from the RT is distributed by gravity to the plumbing instruments in each residential units and supporting facilities, while for processed grey water from WWTP is then collected in recycled ground water tank and pump towards the recycled water roof tank also using transfer pump.

\subsection{Fluctuations of clean water consumption}

Fluctuations data of clean water consumption at Thamrin Residences and Karet Kuningan Apartment were obtained from previous planning by Dimas Swadirasto [6] and Alin Erlita Nurfatiha [7] while in the other two fluctuations data are obtained by direct measurements. Measurements of water consumption in Four Winds and Bellagio Apartments are done through the water meter on each chosen residential. Observations were made by recording water usage every hour for 8 days consisting of 6 working days (weekdays) and 2 days off (weekends) so that water consumption during peak hours on weekdays and weekends can be compared. The data obtained are in units of $\mathrm{m} 3$ per hour and then the percentage of clean water consumption per hour in one day and the average percentage of water consumption during the weekdays and weekend can be calculated. After that, fluctuation data from the comparison apartments will be averaged and the result can be seen in Fig. 1

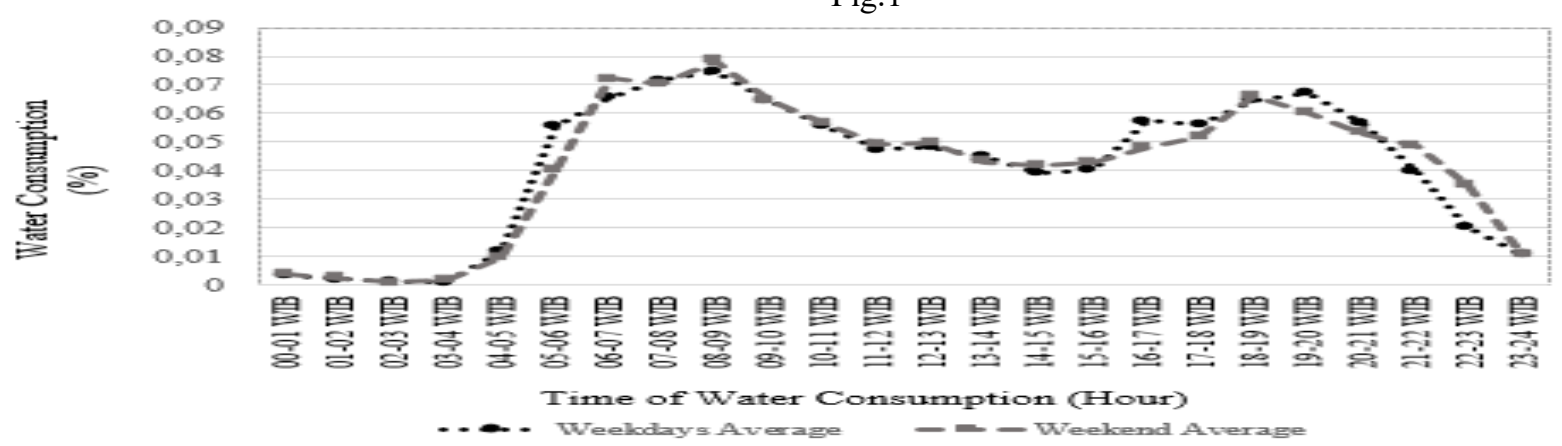

Fig. 1. Fluctuation comparison of average water consumption from the comparative apartments. 
From water fluctuation data, there are three water consumption data, ie Four Winds Apartment for 202 liter/person/day, Bellagio Apartment for 267 liter/person/day, and Karet Kuningan Apartment for 254 liter/person/day. To calculate the water consumptions of Gayanti City Apartment is using the average water consumptions of three out of four comparative apartments while to determine the reservoir capacity is using the fluctuation data of all comparative apartments. This is because the four apartments have a typical lifestyle and occupants and the needs of water are not much different from each other. The more units and the number of occupants, water consumption will be more fluctuate because the possibility of water usage simultaneously decreased.

\subsection{Clean and recycled water needs}

The water needs in three apartments per day is 434,33 $\mathrm{m}^{3}$ of the total occupants are 1778 people, so the water consumption per person is 244 liter/person/day. Water consumption data and the amount of water needed for design apartment is needed to determine the reservoir volume. The water needs at Gayanti City Apartment is divided into the needs of clean water and recycled water. The clean water needed with the amount of 987 people is $116.60 \mathrm{~m}^{3} /$ day and the recycle water needed with the amount of 720 people is $18.64 \mathrm{~m}^{3} /$ day. The assumption of waste water produced is $80 \%$ of clean water, then the amount of waste water produced in this apartment is $93.28 \mathrm{~m}^{3} /$ day.

Black water generated by Gayanti City Apartment is $18.64 \mathrm{~m}^{3} /$ day or $20 \%$ from waste water $(16 \%$ from clean water) while the grey water produced is $74.64 \mathrm{~m}^{3} /$ day or $80 \%$ from waste water (64\% from clean water). Black water flowed into the city sewer while grey water is treated in Waste Water Treatment Plant (WWTP) and then distributed to recycle water treatment to be processed into recycled water that flows as flushing closet and watering plants. The recycled water needs for flushing closet is $18.64 \mathrm{~m}^{3} /$ day so that the total treated water would be $27.96 \mathrm{~m}^{3} /$ day ( $28 \%$ from clean water) and the remaining recycled water of $9.32 \mathrm{~m}^{3} /$ day used for watering plants.

WWTP treated water, that is not distributed to recycle water treatment equal to $46 \%$ of clean water, flowed into the river. Figure 2 shows the water balance of Gayanti City Apartment. From Fig.2, it can be seen the percentage of recycled water obtained from the processing, which is as much as $18 \%$ so that the clean water needs to be saved for next use is $82 \%$ of the amount of clean water. The water balance of Gayanti City Apartment on Fig.2.

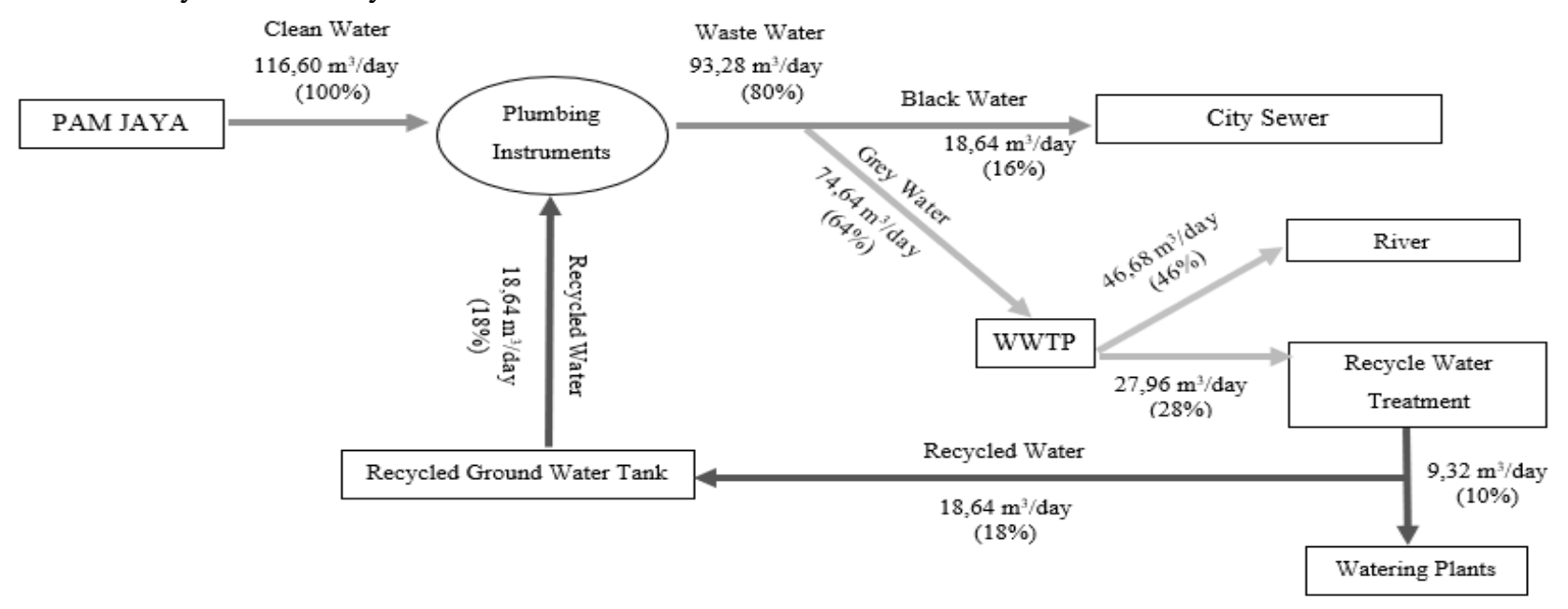

Fig. 2. Water balance of Gayanti City Apartment.

\subsection{Stand pipes, PRV, and booster pump}

Total stand pipes need for this apartment are 18 for clean water and 18 for recycled water based on the chosen design alternatives which is the first alternative. Nine stand pipes are distributed by gravity and the other nine are distributed using booster pump. Booster pump of clean and recycled water is used to distributed water on the top 6 floors starting from $32^{\text {nd }}$ to $27^{\text {th }}$ floor and 4 PRVs are mounted on each stand pipes.

\subsection{Reservoirs and pumps}

In determining the roof tank or upper reservoir capacity of Gayanti City Apartment, the most efficient pumping time is 12 hours of pumping with one time pause starting at $05.00-11.00$ WIB and 15.00-21.00 WIB. The efficiency of its pumping time is $18.40 \%$ so the upper reservoir capacity of clean water is $31.5 \mathrm{~m}^{3}$ and the recycled water is $6.7 \mathrm{~m}^{3}$. The clean water and the recycled water booster pump used are Grundfos in type CR1-7 A-A-E-HQQE $50 \mathrm{~Hz}$ No. 96516176 with clean water operating point at $1.05 \mathrm{~m}^{3} /$ hour and head on 39.87 $\mathrm{m}$ and for recycled water at $1.075 \mathrm{~m}^{3} /$ hour and head on $40 \mathrm{~m}$.

The bottom reservoir or ground water tank is located on the first basement floor. Pumping time for this reservoir is also 12 hours with one time pause when it comes to transferred the water with efficiency of $31.29 \%$ so that clean ground water tank capacity is $123.5 \mathrm{~m}^{3}$ and recycled water is $12 \mathrm{~m}^{3}$. The clean water transfer pump

*Corresponding author: $\underline{\text { ratnaningsih } @ \text { trisakti.ac.id }}$ 
used is Grundfos in type CR 5-32 A-FGJ-AE-HQQE $50 \mathrm{HZ}$ No. 96513393 with operating point at $8.25 \mathrm{~m}^{3} /$ hour and head on $111.11 \mathrm{~m}$. The recycled water transfer pump used is Grundfos in type CR 5-24 A-FGJAE-HQQE 50HZ No. 96513390 with operating point at $6.6 \mathrm{~m}^{3} /$ hour and head on $115 \mathrm{~m}$.

\subsection{Investment and construction cost}

The type of pipes and fittings used in the clean water and recycled water supply is PPR type PN 10 which is sold per pipe with length of 4 meters. Accessories of pipe used are bends (elbow), tees, and water meter. Aside from pipes and accessories, there is also booster and transfer pump. The clean water transfer pump used is Grundfos type CR $5-3250 \mathrm{~Hz}$ and recycled water transfer pump used is Grundfos type CR 5-24 $50 \mathrm{~Hz}$. Each pump consists of two, one for operational and the other as an alternative pump. For clean water and recycled water booster pump are using Grundfos type CR 1-7 $50 \mathrm{~Hz}$. In addition, four PRVs are mounted on each stand pipes. Prices value for clean and recycled water supply is from market prices.

For upper reservoir construction of clean water and recycled water is using panel reservoir with knock down installation system and fiber glass material which cost $\mathrm{Rp} 2,650,000$ per $\mathrm{m}^{3}$, while clean and recycled ground water tank construction are built in concrete frame with price index based on SNI 2835-2008, SNI 6897-2008, SNI 7394-2008, SNI 2837-2008, and Unit Price Analysis (AHS) of SNI 2011. The total investment and construction cost can be seen in Table 1 .

Table 1. Total Cost of investment and construction.

\begin{tabular}{|c|c|}
\hline Description & Cost (Rp) \\
\hline $\begin{array}{c}\text { Clean and Recycled Water } \\
\text { Supply }\end{array}$ & $1,327,532,901$ \\
\hline Reservoir & $309,694,300$ \\
\hline Total & $\mathbf{1 , 6 3 7 , 2 2 7 , 2 0 1}$ \\
\hline
\end{tabular}

\subsection{Efficiency cost of clean water supply}

From the water balance of Gayanti City Apartment, it can be seen that the percentage of recycled water produced is $18 \%$ of the total need for clean water. The next water usage will use recycled water for flushing closet and watering plants so that the percentage of clean water can be saved is $18 \%$ or $18.64 \mathrm{~m}^{3} /$ day. The price of water per $\mathrm{m}^{3}$ for apartment is $\mathrm{Rp} 12,550$ [8].

Then, the efficiency cost of clean water that can be saved from the application of recycling system.

Efficiency Cost :

Clean Water Price per $\mathrm{m}^{3}$ x $18.64 \mathrm{~m}^{3} /$ day

$=\operatorname{Rp} 12,550 / \mathrm{m}^{3} \times 18.64 \mathrm{~m}^{3} /$ day

$=\operatorname{Rp} 233,932 /$ day

$=\operatorname{Rp~7,017,960/month~}$

\section{Conclusions}

The conclusions of this design are as follows, roof tank system is used to distribute clean and recycled water with clean water and recycled water needs of Gayanti City Apartments is $116.60 \mathrm{~m}^{3} /$ day and $18.64 \mathrm{~m}^{3} /$ day. The waste water produced is $93.28 \mathrm{~m}^{3}$ which is $80 \%$ of its is grey water and will be treated in Waste Water Treatment Plant into recycled water. Distribution of clean water and recycled water using 18 stand pipes, consists of 9 gravity stand pipes and 9 booster pump stand pipes. The booster pump is installed on the top 6 floors and the transfer pump pumping time is 12 hours 1 time pause. The source of clean water comes from PAM JAYA DKI. Upper reservoir capacity for clean water and recycled water is $31.5 \mathrm{~m}^{3}$ and $6.7 \mathrm{~m}^{3}$ and ground water tank capacity for clean water or recycled water is $123.5 \mathrm{~m}^{3}$ and $12 \mathrm{~m}^{3}$. The percentage of clean water that can be saved from the application of recycling system is $18 \%$ with efficiency cost of Rp 233,932/day or Rp 7,017,960/month while the investment cost of clean and recycled water supply system and reservoir construction at Gayanti City Apartments is Rp. 1,637,227.201,-

\section{References}

1. Anonim. Peraturan Gubernur Provinsi Daerah Khusus Ibukota Jakarta No 38 Tentang Bangunan Gedung Hijau. (2012)

2. Dhea Yafina Rinka, Moh. Rangga Sururi dan Eka Wardhani. Perencanaan Sistem Plambing Air Limbah dengan Penerapan Konsep Green Building pada Gedung Panghegar Resort Dago Golf Hotel dan Spa. Jurnal Institut Teknologi Nasional Vol 2 No 2. (Reka Lingkungan Teknik Lingkungan Itenas, Surabaya, 2014)

3. Noerbambang, Soufyan M. dan Takeo Morimura. Perencanaan dan Pemeliharaan Sistem Plambing. (PT Pradnya Paramita, Jakarta, 1988)

4. Setiyono. Disain Perencanaan Instalasi Pengolahan Air Limbah (IPAL) dan Reuse Air di Lingkungan Perhotelan. JAI Vol 5 No 2. Jakarta: BPP Teknologi. (2009)

5. Ludwig, A. Create an oasis with Greywater: Choosing, building and using greywater systems. (Santa Barbara, CA, Oasis Design, 2012)

6. Swadirasto, D. Perencanaan Instalasi Plambing Pada Gedung Apartemen Thamrin Residences Tower A, Jakarta Pusat. (Universitas Trisakti, Jakarta, 2008)

7. Nurfatiha, Alin Erlita, Perencanaan Sistem Plambing di Apartemen Karet Kuningan. (Universitas Trisakti, Jakarta, 2017)

8. http://www.biaya.net/2016/08/tarif-air-minumjakarta-pam-jaya-palyja-aetra.html accessed on Thursday, $15^{\text {th }}$ January 2018 at 02.00 WIB. (2016) 